Georgia State University

ScholarWorks @ Georgia State University

1990

\title{
Testosterone, Social Class, and Antisocial Behavior in a Sample of 4,462 Men
}

Robin D. Morris

Georgia State University, robinmorris@gsu.edu

James M. Dabbs

Georgia State University

Follow this and additional works at: https://scholarworks.gsu.edu/psych_facpub

Part of the Psychology Commons

\section{Recommended Citation}

Dabbs, J.M. \& Morris, R. (1990). Testosterone, social class, and antisocial behavior in a sample of 4,462 men. Psychological Science, 1(3), 209211.

This Article is brought to you for free and open access by the Department of Psychology at ScholarWorks @ Georgia State University. It has been accepted for inclusion in Psychology Faculty Publications by an authorized administrator of ScholarWorks @ Georgia State University. For more information, please contact scholarworks@gsu.edu. 


\title{
Research Report
}

\section{TESTOSTERONE, SOCIAL CLASS, AND ANTISOCIAL BEHAVIOR IN A SAMPLE OF 4,462 MEN}

\author{
James M. Dabbs, Jr. and Robin Morris \\ Department of Psychology, Georgia State University
}

\begin{abstract}
Two hypotheses have been offered to explain the relation between testosterone and antisocial behavior in delinquent and criminal populations. One is that testosterone leads directly to antisocial behavior. The other is that a constellation of dominance, competitiveness, and sensation seeking associated with testosterone leads to either antisocial or prosocial behavior, depending upon an individual's resources and background. Analysis of archival data from 4,462 U.S. military veterans supported the first hypothesis: Testosterone was correlated with a variety of antisocial behaviors among all individuals. However, socioeconomic status (SES) proved to be a moderating variable, with weaker testosterone-behavior relationships among high SES subjects.
\end{abstract}

Testosterone has been related to human antisocial behavior, but primarily in delinquent and criminal populations. It has been found that prison inmates high in testosterone are more likely to have committed violent crimes (Dabbs, Frady, Cart, \& Besch, 1987; Dabbs, Ruback, Frady, Hopper, \& Sgoutas, 1988; Ehrenkranz, Bliss, \& Sheard, 1974), engaged in criminal activity at an early age (Kreuz \& Rose, 1972), been more dominant in prison and violated prison rules more often (Dabbs et al., 1987; Ehrenkranz et al., 1974), and been judged more severely by parole boards (Dabbs et al., 1988; Kreuz \& Rose, 1972). Testosterone in adolescent males has been associated with dominance, leading especially to delinquency when they feel unfairly restricted (Olweus, 1983) or prematurely try to engage in activities (especially involving sex, drugs, alcohol, and tobacco) usually reserved for older persons (Udry, 1989).

Focussing on criminals and delin-

Correspondence and reprint requests to James M. Dabbs, Jr., Department of Psychology, Georgia State University, Atlanta, GA 30303 . quents, however, may obscure more positive relationships. Daitzman and Zuckerman (1980) suggest that testosterone is related to a general sensationseeking tendency Sensation seeking can have positive or negative effects, depending on one's social background and resources. Individuals low in socioeconomic status (SES) often find the most exciting things to do are illegal, while high SES individuals can do things that are both exciting and socially acceptable-driving fast cars instead of stealing them, arguing instead of fighting, playing college football instead of assaulting. Data from a large sample of normal adults could help clarify the relationship between testosterone and behavior.

We obtained such data from a study of 4,462 male U.S. military veterans. These men, half of whom had served in Vietnam during 1965-1971, were studied beginning in 1985 to assess long-term effects of the Vietnam military experience (Centers for Disease Control, 1988). Their mean age was 37 years, and they were representative of the U.S. population in race, education, income, and occupation. All had been enlisted men. They were interviewed by telephone and underwent extensive medical, psychological, neuropsychological, and laboratory examinations at the Lovelace Medical Foundation (Albuquerque, NM). Laboratory examinations included assays of testosterone in serum samples collected in the morning before eating; the coefficient of variation (CV) among quality control samples was less than $10 \%$. Subjects completed the Minnesota Multiphasic Personality Inventory and were interviewed using the Diagnostic Interview Schedule (DIS), which provides information on DSM-III psychiatric diagnoses (American Psychiatric Association, 1980). The DIS was modified to include additional items on antisocial behavior. The present paper examines relationships between subjects' testosterone levels and reports of their own behavior.
Following the epidemiological approach used by the Centers for Disease Control (CDC) in the original study, we treated testosterone as a risk factor that might increase the likelihood of antisocial behavior. This approach dichotomizes continuous variables and thus loses some information, but it has the advantage of focussing attention directly on the behavior of extreme groups. We classified subjects as high in testosterone if they were in the upper $10 \%$ of the distribution and as normal if they were in the remainder of the distribution. We then computed ratios to contrast the risk (or likelihood) of various behaviors in the high testosterone group with the risk of these behaviors in the normal testosterone group. For example, a risk ratio of 2.0 would indicate a given behavior was twice as probable in the high as in the normal testosterone group. A risk ratio is considered statistically significant ( $p<.05$ ) when its $95 \%$ confidence interval excludes 1.0. Risk ratios were adjusted (SAS Institute, 1985) for subjects' age, race (white or nonwhite), and place of service (Vietnam or other), variables that might plausibly affect the testosterone-behavior relationship.

The findings are summarized in Table 1. The behaviors in Table 1 are described in footnotes to the table; they are as defined in the original CDC data set. These behaviors occurred at times ranging from childhood to the recent past. Individuals higher in testosterone more often reported having trouble with parents, teachers, and classmates; being assaultive toward other adults; going AWOL in the military; and using hard drugs, marijuana, and alcohol. They also reported having more sexual partners. The overall picture is one of delinquency, substance abuse, and a general tendency toward excessive behavior.

We then examined SES, to see if it moderated the testosterone-behavior relationship. There was relatively little social class information in the data set, and we used subjects' education and current 
Testosterone and antisocial behavior

Table 1. Pcrcentage of normal and high testosterone subjects reporting high levels of rarious behaviors

\begin{tabular}{|c|c|c|c|c|}
\hline \multirow[b]{2}{*}{ Behavior } & \multicolumn{2}{|c|}{ Group } & \multirow[b]{2}{*}{ Risk Ratio } & \multirow[b]{2}{*}{$\begin{array}{l}\text { 95\% Confidence } \\
\text { Interval }\end{array}$} \\
\hline & $\begin{array}{c}\text { Normal Testo } \\
(n=4,016)\end{array}$ & $\begin{array}{l}\text { High Testo. } \\
(n=446)\end{array}$ & & \\
\hline Childhood delinquencya & 11.5 & 17.9 & 1.4 & $1.1-1.8$ \\
\hline Adult delinquency ${ }^{\mathrm{h}}$ & 10.0 & 22.6 & 1.9 & $1.6-2.3$ \\
\hline Hard drug use & 9.7 & 24.7 & 2.1 & $1.8-2.6$ \\
\hline Marijuana use & 22.5 & 47.6 & 1.8 & $1.6-2.0$ \\
\hline Alcohol abuse & 11.5 & 16.4 & 1.4 & $1.1-1.7$ \\
\hline Military AWOL d & 5.9 & 13.4 & 1.8 & $1.3-2.3$ \\
\hline Many sex partners ${ }^{c}$ & 23.1 & 32.1 & 1.3 & $1.1-1.5$ \\
\hline \multicolumn{5}{|c|}{$\begin{array}{l}\text { * Mantel-Haenszel relative risk ratios, adjusted for age at time of hormone assay, race (white vs. } \\
\text { nonwhite), and place of military service (Vietnam vs. other). } \\
\text { a In upper } 10 \% \text { of sample in number of DSM-III conduct disorder problem areas before age 15, including } \\
\text { poor grades, trouble in school, truancy, being expelled or suspended, running away from home, starting } \\
\text { fights, lying, stealing, vandalism, being drunk or using drugs, and being arrested. } \\
\text { " ln upper } 10 \% \text { of sample in number of DSM-III antisocial personality symptoms since age } 18 \text {, including } \\
\text { assaultive marital or relationship problems, negligence toward children, job trouble, trouble with debts, } \\
\text { traffic offenses, non-traffic arrests, lying, violence, and vagrancy. } \\
\text { "Alcohol abuse/dependency in year preceding interview. } \\
\text { d Lost service time for absence without leave or other misbehavior. } \\
\text { "Had } 10 \text { or more sex partners in one year. }\end{array}$} \\
\hline
\end{tabular}

housebold income to determine their SES. Education and income weigh heavily in measures of SES (Miller, 1983). We classified subjects as low or high in SES if they were, respectively. below or above the 1985 U.S. population median in both income and education. This dual criterion excluded $39 \%$ of the subjects, who were high in income and low in education, or vice versa, but it produced a relatively clear distinction between low and high SES groups.
More of the low than the high SES subjects were in the upper $10 \%$ range in testosterone $14 \%$ vs. $6 \%, p<.001$ by chi-square test). We computed testosterone risk ratios separately for low and high SES groups, again adjusting for age, race, and place of service (Table 2). Marijuana use was significantly related to testosterone in both SES groups, but the other behaviors were significantly related to testosterone only in the low group. Risk ratios for adult delinquency and hard drug use were twice as great in the low as in the high SES group.

We conclude that testosterone is related to antisocial behavior, is lower among subjects who are higher in SES, and is less strongly related to antisocial behavior among subjects who are higher in SES. Testosterone is thus directly associated with many negative effects. While high testosterone theoretically might lead to prosocial behavior, the present data provide no indication of

Table 2. Socioeconomic status (SES) differences in percentage of normal and high testosterone subjects reporting high levels of various behaviors

\begin{tabular}{|c|c|c|c|c|c|c|}
\hline \multirow[b]{2}{*}{ Behavior } & \multicolumn{3}{|c|}{ Low SES } & \multicolumn{3}{|c|}{ High SES } \\
\hline & $\begin{array}{l}\text { Normal Testo. } \\
(n=1,294)\end{array}$ & $\begin{array}{l}\text { High Testo. } \\
(n=202)\end{array}$ & Risk Ratio ${ }^{a}$ & $\begin{array}{l}\text { Normal Testo. } \\
(n=1,167)\end{array}$ & $\begin{array}{l}\text { High Testo. } \\
\qquad(n=73)\end{array}$ & Risk Ratio ${ }^{\mathbf{a}}$ \\
\hline Childhood deliquency & 14.2 & 21.8 & $1.5^{*}$ & 8.6 & 11.0 & 1.1 \\
\hline Adult delinquency & 14.7 & 30.7 & $1.9^{*}$ & 4.5 & 4.1 & 0.9 \\
\hline Hard drug use & 10.0 & 29.2 & $2.5^{*}$ & 7.5 & 12.5 & 1.3 \\
\hline Marijuana use & 23.6 & 51.0 & $1.8^{*}$ & 18.4 & 37.5 & $1.8^{*}$ \\
\hline Alcohol abuse & 18.1 & 27.7 & $1.4^{*}$ & 11.8 & 11.1 & 1.0 \\
\hline Military AWOL & 9.8 & 19.1 & $1.5^{*}$ & 2.2 & 4.1 & 1.7 \\
\hline Many sex partners & 23.6 & 33.3 & $1.4^{*}$ & 21.4 & 28.8 & 1.3 \\
\hline
\end{tabular}

NOTE: Of the original 4462 subjects, $39 \%$ were excluded because they were not clearly high or low in SES.

"Mantel-Haenszel relative risk ratios, adjusted for age at time of hormone assay, race (white vs. nonwhite), and place of service (Vietnam vs. other).

* $95 \%$ confidence interval excludes 1.0 . 
such redeeming social value. Prior findings emphasize the importance of testosterone in individual confrontations (Bernstein, Rose, \& Gordon, 1974; Mazur. 1985). Individuals high in SES tend to avoid individual confrontations, especially physical ones, and to submit to years of schooling. Perhaps the antisocial behavior associated with high testosterone interferes with education, but those individuals who do become highly educated are better equipped to control their antisocial tendencies. We do not yet know whether the relationship of testosterone to education and SES involves only motivational factors, or whether cognitive factors are also involved (Christiansen \& Knussmann. 1987).

The statistical power provided by the present sample of 4,462 subjects is extraordinarily high. With a sample this large, for example, Pearson $r=.05$ is significant at $p<.001$. The effects reported in the present paper are relatively small in size and account for appreciable variance only at extreme levels of testosterone. This fact may help us understand why the results of previous studies have not always been consistent. Previous studies have generally employed small samples, and only with large samples can one see clearly the relationship of testosterone to antisocial behavior.

Acknowledgments-This research was supported in part by grant MH42525 from the Antisocial and Violent Behavior Branch of the National Institute of Mental Health. The data were originally gathered as part of the Vietnam Experience Study, conducted by the Centers for Disease Control, U.S. Public Health Service, under a cooperative agreement with the Veterans Administration.

\section{REFERENCES}

American Psychiatric Association. (1980). Diagnostic and statistical manual of mental disorders (3rd ed.). Washington, DC: Author.

Bernstein. I.S., Rose, R.M., \& Gordon. T.P. (1974). Behavioral and environmental events influencing primate testosterone levels. Journal of $\mathrm{Hu}$ man Evolution, 3, 517-525.

Centers for Disease Control. (1988). Health status of Vietnam veterans. Journal of the American Medical Association, 259, 2701-2719.

Christiansen, K., \& Knussmann, R. (1987). Sex hormones and cognitive functioning in men. Neuropsychobiology, 18, 27-36

Dabbs, J.M., Jr., Frady, R.L., Carr, T.S., \& Besch,
N.F. (1987). Salvia testosterone and criminal violence in young adult prison inmates. Psychosomatic Medicine, 49, 174-182.

Dabbs, J.M., Ir., Ruback, R.B., Frady, R.L., Hop per, C.H., \& Sgoutas, D.S. (1988). Salvia testosterone and criminal violence among women. Personality and Individual Differences, 9, 269-275.

Daitzman, R., \& Zuckerman, M. (1980). Disinhibitory sensation seeking, personality and gonadal hormones. Personality and Individual Differences, $1,103-110$.

Ehrenkranz, J., Bliss, E., \& Sheard, M.H. (1974). Plasma testosterone: Correlation with aggressive behavior and social dominance in man. Psychosomatic Medicine, 36, 469-475.

Kreuz, L.E., \& Rose, R.M. (1972). Assessment of aggressive behavior and plasma testosterone in a young criminal population. Psychosomatic Medicine, 34, 321-332.

Mazur, A. (1985). A biosocial model of status in face-to-face primate groups. Social Forces, 64 , $377-402$.

Miller, D.C. (1983). Handbook of research design and social measurement. New York: Longman.

Olweus, D. (1983). Testosterone in the development of antisocial behavior in adolescents. In K.T. VanDusen \& S.A. Mednick (Eds.), Prospective studies of crime and delinquency. Boston: Kluwer-Nijhoff.

SAS Institute. (1985). SAS user's guide: Statistics (Verson 5 ed., pp. 422-423). Carey, NC: Author.

Udry, J.R. (1989). Biosocial models of adolescent behavior problems. Unpublished manuscript, University of North Carolina, Chapel Hill.

(RECEIVED 8/24/89; ACCEPTED 10/11/89) 
This document is a scanned copy of a printed document. No warranty is given about the accuracy of the copy. Users should refer to the original published version of the material. 